Erkki Kaukonen, Pirkko-Liisa Rauhala

\title{
Structural transformation of science: trends and problems of scientific integration
}

\section{Introduction}

From a structural point of view, the entire history of science appears as a history of continuous cognitive and institutional differentiation, with new fields of research being born and becoming independent in various institutional settings. Furthermore, there is no evidence that this development would be coming to an end or approaching a point of saturation. On the contrary, the diversification of the system of science seems to continue at an accelerating pace.

What does this structural process mean from the point of view of scientific integration? Does the ongoing differentiation advance our knowledge and understanding of the increasingly complex world around us? Or does it just bring about more diversity and fragmentation in science? Is it at all legitimate to talk about integration in science as a reasonable objective? If yes - as we think - then what are the main restraints and potentials of integrative development in the contemporary research system? In this article the problems connected to the structural transformation of science will be discussed from this perspective.

Our main presumption is that there is a continuous reflective process going on between science and society. The internal structure and ethos of science is being influenced and modified by the growing external preassures put on science by economic, political and other social forces. There is also a basic structural tension between the differentiation of (basic) science and the division of social institutions, e.g. the welfare-state service system, which an sich is political, economical and social, needs and uses specialized knowledge like the results of medicine, pedagogical sciences, and technics. Thus the institutional settings of science embody both cognitive and social aspects. As a part of society science has its hierarchies. One of these is the problematic relation between center and periphery.

The differentiation of scientific activities has been necessary for the advancement of science, or its 'internal logic' of development. Specialization is a way of acquiring analytic and specific knowledge of the various aspects of reality. The history of science, however, cannot be reduced to any pure logic, because the development of the scientific 'enterprise' is, and has always been, socially mediated. Our present picture of science and the structure of science itself is essentially modified by Western culture and the centuries-long development of capitalism (e.g., Elzinga and Jamison, 1981; Restivo, 1988).

The interconnected driving forces of scientific research, i.e. the cognitive and the social pursuits, have resulted in the increasing structural diversity and heterogeneity of science. Related to this, serious 
doubts have been raised as to the ability of the dominant modes of science - the academic and the industrial - to confront the major problems of contemporary reality (Nakayama, 1981). Structural constraints in the present system of science have become manifest in efforts to promote the study of such complex and socially significant issues as perspectives on national and global social development, world economic process, problems of developing countries and ecological problems (e.g. Our Common Future, 1987). The advancement of these areas of research is not possible without the integrative efforts of scientists from different disciplinary and institutional backgrounds. No less necessary would be a substantial restructuring of research funding and organization. This demonstrates the complexity of problems encountered in efforts at scientific cooperation and integration. Thus, in analyzing the structural development of science the various interconnected aspects of this development - cognitive, communicative, institutional and societal - should be taken into account (Kaukonen, 1985).

\section{Institutional restructuration of science}

Although science always evolves through and by virtue of scientific activity, the determinants of its development basically pertain to the objective environment of science. In this regard one can distinguish the social context of science, on the one hand, and the object of science, the specific reality it studies, on the other. Metaphorically speaking, the social context of science constitutes its mundane 'background', whereas the object of research, conceptualized and approached through a scientific tradition, may be called its cognitive 'horizon'. Whitley (1974) illustrates this process with the concepts of social and cognitive institutionalization. The abating debate on internalism vs. externalism in science studies (for a late example see Shapere, 1986) basically concerned this relationship and the way it is mediated in scientific thought.

In mapping the differentiation of science one can distinguish two kinds of analytical coordinates: the one related to the scientific substance of research problems, the other pertaining to the interconnection of science and society, often illustrated with the distinction of basic and applied research. The relationship of these coordinates is considered a basic factor in our attempt to explain why there are such great differences in the scientific character, in the institutional and organizational forms and in the social functions of various disciplines, scientific fields and specialties. The location of scientific fields on this 'map' has objective impact on the way the 'scientific' and the 'social' become concretely interconnected in the everyday life of science. This means, for instance, that the development of some scientific fields is socially more sensitive than that of others. This may be due either to the nature of research problems and their closeness to social practice and interests (e.g. the social sciences), or to the aims and institutional profile of research (e.g. applied $R \& D$ and its subordination to social objectives). This position, however, does not mean support of epistemological relativism (e.g., Yakhiel, 1985).

Institutional structures in a way play a contradictory, double role in the development of science. On the one hand, as an intermediary link in the interconnections between science and society, institutional forms reflect the intrinsic needs of scientific work and its objectives, and give it relative autonomy (Titmonas, 1974: 170-72). On the other hand, they filter external societal influences on science. The emergence of new institutional structures usually presupposes material support from external sources. The scientific communities may of course contribute to the process, but without support from extra-mural sponsors their possibility to influence science policy decisions remains limited.

Scientific activity is located at the intersection of two analytically distinct structures: the institutional structure, which is a materialized result of the encounter and 'fusion' of social and scientific interests, and the cognitive structure, which reflects the substantive state and dynamics of scientific research. For scientific activity, institutional structures function as objective conditions that impose a certain profile and normative structure on research and its evaluation (e.g., Nakayama, 1981; Ziman, 1984; Broesterhuizen and Rip, 1984). Therefore, a distinction should be made between different institutional types of science. Four basic, or in a Weberian sense, ideal types of science can be distinguished according to their specific institutional profile and dynamics (cf. Kara-Murza, 1986).

1. Academic science (Scientific Societies and Academies) was born in the seventeenth century apart from the scholastic university system and received its autonomy as a result of a socio-political 'contract' committing the academies to noninvolvement in religion, politics, teaching and other "dangerous elements" (Elzinga and Jamison, 1981: 42-43). The emphasis in academic science has thus been on systematic basic (or 'pure') research. At the same time, however, scientific societies often 
proved to be more dynamic than the universities and other research institutions in advancing interdisciplinary research and scientific communication. The role, organization and university connections of academic science greatly vary in different countries.

2. Universityscience has a long scholastic tradition largely resulting from its close connections to educational functions defined by external authorities, such as the church, the state and professional groups. This dependence has had, and still has, a substantial impact on the development of disciplinary structures and research in the universities. In spite of the 'invasion' of scientific research in the universities in the nineteenth century, they still can be often characterized as institutionally and organizationally conservative and non-dynamic. Perhaps traditional, university based disciplines embody best the features ascribed to scientific establishments by Elias: because they are like sovereign states, which rank in status and power, and differ in their traditional ideologies and values, "interdisciplinary collaboration, at present, is exceedingly difficult and almost impossible in many cases" (Elias, 1982: 25-26). University departments are not only discipline-organized; they are also educational, administrative and economic entities, competing with each others (Bourdieu, 1975). Recently in many countries the universities have become more dependent on various external sources of support and transformed their profile toward 'multiversities', a hybrid structure combining different and even contradictory functions.

3. Governmental or sectoral R\&D (state research institutes and units) is typically characterized by its subordination to political and bureaucratic goals and administrative sectorialization. Research is typically narrow, low-profile and mission oriented. Resulting from 'advocative' functions the theoretical and critical degrees of freedom of research are limited and not all of the research results are made public. A striking example of this kind of subordination is offered by the Finnish forest research, the development of which has been tightly connected to economic utility and the interests of forest industry (Alestalo, 1981). This has meant that broader conceptualizations and alternative approaches to forest issues have been opposed by the sectoral research authorities (Lähde, 1988).

4. Industrial R\&D has been, for some time, the most rapidly expanding sphere of research in the capitalist countries. Industrial R\&D is basically private, in-house business, with goals set and results assessed inside the financing agency or corporation. It is typically organized in dynamic but distinctly defined projects aiming at the development of new competitive technologies and products. The recent development of so-called strategic research, often co-sponsored by the government (see Irvine and Martin, 1984), has increased the share of basic research and the use of social science consulting in big industrial corporations. This has resulted in breaking down the traditional institutional barriers between the private, governmental and academic sectors of research and led to the emergence of new connections. As Nakayama (1981: 89) notes, even "academic science has been caught up in the powerful mechanisms of industrialized science and confirmed itself to them as a sub-contractor". During the last years the major industrial corporations for example in the US have established new kinds of consortia and institutes to promote industrial $R \& D$ at the "precompetetive" level in selected strategic areas in cooperation with the government agencies and the universities (Etzkowitz, 1989, see also 1983).

The four institutional types of research locate themselves roughly, in the given order, on the dimension of autonomous basic research - practice dependent, applied research and development. Of course, no pure types exist in reality and the institutional structure of science also varies considerably from country to country. Some examples of national structural specifics are: the development of a systematic and relatively independent structure of Academies of Science in socialist countries; military-technological big science in the center countries of international politics; the dominance of corporation based industrial research most prominently in Japan (ca. $75-80 \%$ of total research funding); and organizationally less differentiated $R \& D$-systems in small countries like Finland.

\section{Structural trends in the development of science}

The major historical changes in the overall system of science indicate two historical trends (cf. Granö, 1981: 9). First, the institutional settings and organizational forms of research have become increasingly diverse, the most crucial changes being of a very recent origin. Secondly, the center of scientific activities has been shifting from academic basic research to practically oriented $R \& D$; from scientific societies and universities to big corporations and governmental agencies, or, from the public and open 'republic of science' to the nonpublic and closed system of scientific "enterprises". 
In Finland the structural transition from the primacy of the humanities and traditional academic science to the dominance of technological $R \& D$ has taken place in less than thirty years. Concomitantly, the public image of science has changed drastically from the 1950's to the 1980's. (Kaukonen, 1987; Lemola and Lovio, 1989).

An estimated $70-80 \%$ of all research done in the leading industrialized countries is more or less secret or non-public for military, political, business, or other reasons and does not get publicly evaluated and utilized, even though it is often substantially supported from public funds (cf. Gibbons and Wittrock, 1985). Obviously only a marginal and diminishing part of research activities somehow meets the traditional institutional criteria of science. This development implies a paradoxical diagnosis: an increasing share of science (epistemological criteria) results from non-science (institutional criteria). These changes will probably create increasing tensions between the traditional scientific ethos and the differing goals of new institutional environments (see Stolte-Heiskanen, 1987). For instance, the universities are facing a threat of becoming 'colonialized' by private industries and other external interest organizations as the dependency of universities on contract research funding increases. This development will result in a growing pressure toward privatization of research results and, hence, in erecting new barriers for scientific communication (e.g. Raa, 1987). Pressures to secrecy are strongest in research fields like biotechnology where major economic profits can be anticipated in the future.

The expansion of the 'black box' in science should also worry those doing science and science policy studies. If the trends continue, the object of these studies will soon disappear behind closed doors. This problem already makes it difficult to draw a comprehensive and realistic picture of today's science and its cognitive potential. For instance, we have little information about the contents and

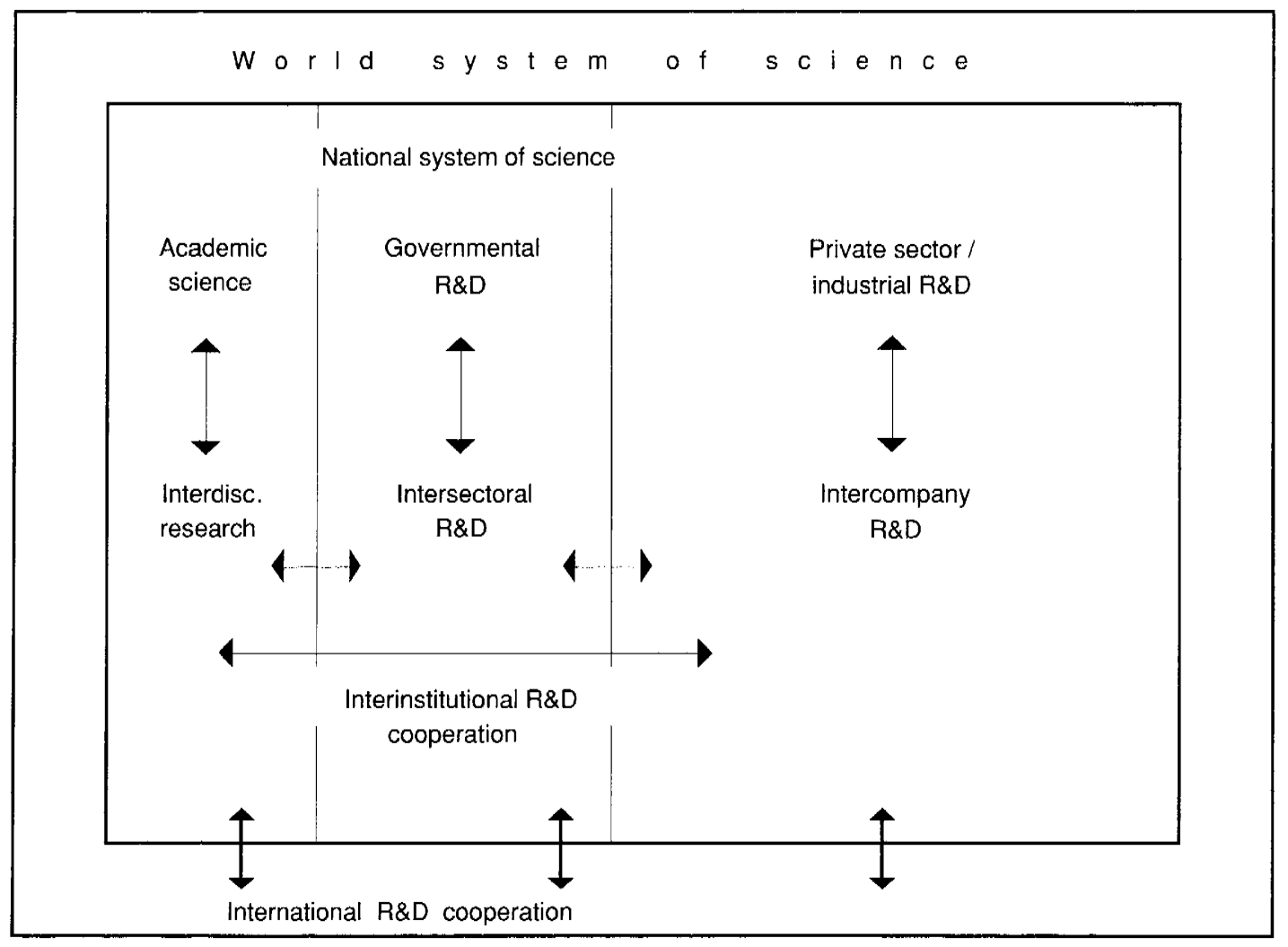

Figure 1. Structural elements of science and their types of interconnections. 
organization of strategic research of big multinational corporations and thus cannot judge their quality. Our guess, however, is that they are more integrative than the academic ones. The relevant results of academic and sectoral research are open to the closed corporations and agencies. At the same time the strategic goals imposed on industrial research make it necessary, and dynamic project funding feasible, to arrive at practically applicable, i.e. in sufficient degree integrated results.

In Figure 1 the structural elements of science and their respective types of interconnections are presented schematically. As an illustration the space given to each sector approximates the present situation in Finland ${ }^{3}$. Academic science here refers to both universities and scientific societies/ academies.

The figure illustrates the diverse character of internal relations in the overall $R \& D$ system and points to the manifold problems faced by attempts to coordinate science and technology policy. It seems to us that the least developed links in the scheme are in the areas of interdisciplinary, intersectoral and interinstitutional (academic governmental) cooperation, due mainly to the institutional constraints and characteristics outlined above. On the other hand, international, intercompany and government-industry connections seem to be relatively more developed. From the point of view of the social functions and responsibility of science, the relationship of the scientific community to the public is an important dimension to be added to the scheme, especially when this connection is the most underdeveloped, reflecting the isolation of science from civil society (see Nakayama, 19814; Elzinga, 1988). These major structural problems notwithstanding, the following study must be limited to the problems of scientific integration in the most visible, academic sphere.

\section{The idea of scientific integration: a historical perspective}

The idea of scientific integration is based on the simple epistemologic-ontological assumption that the object of research - nature, wo/man, society constitutes a totality or diverse unity in which the various parts and aspects of reality are interconnected in one way or another. Thus, insofar as science strives for objective and adequate cognition of its object, it also should progress towards diverse unity, i.e. scientific integration (e.g. Kedrow, 1971).

Of course, we do not have pure ontological knowledge of reality and thus cannot tell how integrated the world 'really' is. Our present concept of reality is largely produced and mediated by science itself. The picture that science offers is not uniform, however. While scientific abstractions and concepts mainly divide the world, scientific knowledge also convinces us about the common (material) origins of the evolution of nature, wo/man and society. In our view, there are good grounds to maintain that social reality or man is more integrated than the theories and concepts produced about it. Apart from materialistic arguments, this assumption can also be based on the observation that the social mechanisms in academic science work rather for compartmentalized than over-integrated knowledge. From another perspective, the growing importance of global problems and their complex interconnections also necessitate the advancement of more integrative and comprehensive approaches and efforts in science, both natural and social (Legay, 1986). If these epistemological, sociological and science policy points of view are accepted, it is evident that the degree of scientific integration constitutes one of the criteria of scientific progress as defined in realistic terms.

During the history of Western science, the question of scientific monism or unity has from time to time become accentuated. One can cite Greek philosophers, medieval scholars, Francis Bacon, the French encyclopedists, the Humboldtian neoclassical university idea, Marx and Engels, the logical positivists of the Vienna circle, and, more recently, several Soviet philosophers ${ }^{5}$. Marx, for instance, explicitly expressed his standpoint in anticipating 'the coming of one science' (Marx, 1844: 115). More elegantly, however, the same idea was expressed by Michelet, a French historian who wrote in 1825 (without any materialistic argument, though):

"Such is the progress of human mind: it sees first science, and then the sciences, and then again science. It sets out of unity, but from a unity of confusion and chaos, and it returns to unity, but to a unity of order and light." (Quoted from Gusdorf, 1977:585).

This beautiful but over-romantic formulation crystallizes the development of scientific knowledge into a pure logical and cognitive model. It comes close to the Marxist idea of the dialectics of abstract and concrete (respectively, analysis and synthesis) in the process of human cognition (e.g., Rosental et al., 1974; Kedrow, 1980). Yet the real historical development of science somehow resembles this logical ideal.

A great many of the scholars and philosophers of 
the 18th and 19th centuries were puzzled by the question of how nature influences society, on the one hand, and how society has emerged historically apart from nature, and civilized man developed from the primitive, on the other (Kon, 1979). Paradoxically, the questions concerning the fundamental evolution of both nature and society led to further differentiation of research ${ }^{6}$. This structural change has been reflected in various attempts at the classification of scientific disciplines systematically developed during the past two hundred years (Kedrow, 1975 and 1976).

When periodicizing the structural development of science at a very general level, three main phases may be differentiated. First, the era of undifferentiated non-disciplinary science, a primary example of which was Greek antiquity with its philosophically oriented holistic thinking about man, nature and society (Volkov, 1976: 152-174). Second, the era of scientific differentiation, beginning in the 16th and 17th centuries, which was characterized by the emergence of new independent disciplines in an 'empty space', with little connections to other parts of science. At the same time, the philosophical frame of research was broken and the hierarchy of science became restructured. New independent disciplines emerged 'from below" first mechanics and physics, then chemistry, biology, etc., which brought about the positivistic ideal of science and the concomitant reductionist tendencies, on the one hand, and the dualism of 'science'and 'humanities', on the other (e.g. Elias, 1982: 53-69).

The newest era of differentiation and integration began in the nineteenth century and continues to our time. From a structural point of view, the essential difference is that now new disciplines and scientific fields by necessity also have integrative functions in the sense that they build bridges between two or more already existing disciplines, e.g. biochemistry, biotechnics, social psychology. Disciplines of a new type have emerged, too. Scientific specialties like cybernetics, informatics and systems theory are transdisciplinary in the sense that they provide a common and potentially unifying framework for scientific fields which differ in their substance. There are also new kinds of problem-based research areas, such as peace research, social policy research, public health studies, development studies, environmental studies, women's studies, etc. Even if the emergence of these research areas has been closely connected with social movements and objectives, and their scientific status has often remained ambivalent, they none the less constitute a growing potential for scientific integration (cf.
Nakayama's "service science", 1981).

As a result of these bridge-building processes, the net of science has become all the more dense. To develop the net metaphor further one may ask, however, if only small fish are caught in a net with small meshes while the big ones swim through? Or, why does not the increased wideness, density and sophistication of the scientific network automatically lead to scientific integration at the cognitive level? - Obviously, the basic question concerns the durability of the net.

\section{Restraints and potentials of integrative development}

As indicated above, the problem of integration fundamentally pertains to the adequacy of scientific knowledge and cognition. At the same time it constitutes a complex and multifaceted issue involving all aspects of science. Accordingly, the problems of scientific integration should be dealt with at the four interdependent levels of (1) institutional structure, (2) scientific communication, (3) cognitive structure, and (4) social relevance of research and science policy priorities ${ }^{7}$

Institutional boundaries of academic science parallel disciplinary structures, which at the universities have been closely related to the development and differentiation of educational and professional functions. While protecting the relative autonomy of the discipline, the institutional structure tends to legitimate the division of academic science into 'monopolized territories'. Institutional structures also have a more practical bearing on the problem of scientific integration: there rarely exist material resources or administrative prerequisities for cooperation between different disciplines. Interdisciplinary contacts often remain on the level of informal organization. Professional and collegial interests also give rise to 'boundary work'; i.e. attempts to legitimate the prevailing demarcation between disciplines (Gieryn, 1983; Merton, 1973: 49-53). An interdisciplinary orientation therefore often implies the professional risk of getting lost in no man's land. An example of this problematique is offered by the interdisciplinary cooperation within medical sciences: both social scientists and natural scientists are outsiders in the field of "medicine proper" (see Hamburg and Brown, 1978).

Broadly defined, scientific communication is an integrative concept which unites the different aspects of science and gives them concrete content and meaning. Thus the 'internal' and 'external' factors of science are inherently combined in scientific 
communication. This means that in practice it is not possible to distinguish scientific communication defined by cognitive criteria from communication in science defined by social and institutional criteria (cf. Mulkay and Gilbert, 1983). Therefore also the institutional and cognitive problems of scientific collaboration are merged in communicative practice.

A specific feature of the academic system is its heavy emphasis on individual competition and evaluation (e.g. Bourdieu, 1988). This promotes the fragmentation of research while everybody has to find his/her own 'niche' in order to make a valued academic contribution (of course, there are differences in individuality/collectivity in different fields). This tendency is reinforced by the continuing specialization of higher education, which is an essential mediating mechanism in the reproduction of scientific knowledge and tradition.

The consequences of these processes on scientific communication have been expressively described by Gusdorf (1977: 568,588$)$ : "the evil of specialization causes mental sclerosis. Knowledge ceases to be a relationship to the real world, and cultivates increasingly narrow systems of abstraction which do not communicate with each other". The quotation indicates that the failures of scientific communication basically emanate from excessive cognitive specialization and concomitant alienation of scientific research from practice. The processes of differentiation are not purely cognitive, however. They are mediated by institutional factors, such as the organization of research work, which effect the development of communicative infrastructure, and thereby also the degree of mutual understanding (cf. Koivisto 1953: 470).

The cognitive structure of science, as its most dynamic element, has a kind of double function in science. It constitutes the end result of scientific activity, and the basic archive for the reproduction of scientific knowledge. A considerable part of research output is buried in the archive with no impact on others' work. Therefore an important practical question to be studied further is: in what degree do the results communicate to colleagues and other relevant audiencies, and what effects do they have?

Ultimately, the question of scientific integration concerns the internal relations of scientific theories, methods, and concepts and their potential to grasp the complex problems of reality. Without going into a more detailed discussion, three general remarks are in order. First, historical evidence shows that reductionist attempts to develop a 'unified science' based on any one fundamental discipline (e.g. mathematics and physics, advocated by the Vienna circle) have failed. Therefore real progress is possible only when the qualitative specifics and relative autonomy of different disciplines are acknowledged (Elias, 1982: 59-66). Secondly, in order to make advances in an integrative direction, attempts to combine and merge disciplinary thought with problem-oriented research will be necessary, otherwise there is a danger that the latter will grow apart from the disciplinary structures, with detrimental effects on both. Thirdly, integrative thinking presupposes increasing self-reflexivity from the scientific community, a consciousness of the nature, social connections and conditions of research work. Since the need for scientific integration arises from the complexity of real world problems, the scientific community must also be more aware of the social relevance of research and of its own social responsibility.

At the level of science policy, questions pertaining to institutional development, financing and research priorities are essential (see Radnitzky, 1983). As described above, recent tendencies in the structural development of science are not promising in this respect. The share of public science is diminishing while the most integrated, strategic research is mainly carried out in secrecy. In addition, one-sided technological orientation is gaining ground in governmental research policy and thus leaving less room for complex interdisciplinary projects going beyond the technological regime.

In the early and mid 1970's there were serious attempts to move in the other direction. At that time in Finland - as in many other countries inspired by the OECD policies - a comprehensive science policy program was issued with wide social science oriented priority areas defined on the basis of the objectives of democratic social policy. This program was fulfilled only in part because it met resistance and criticism from both university circles and conservative political forces.

In our view, the full realization of the program was also hindered by the academic community's inability to transform the complex priority areas into genuine interdisciplinary research agendas and scientific problems (Mäkelä, 1981:46). It is rather paradoxical that now, when the academic community would be professionally better equipped to carry out similar programs, they have been largely replaced by technology development priorities which often are taken as socially non-problematic (Kaukonen, 1986: 38). One may anticipate, however, that the problems of societal development will, sooner or later, give rise to new demands for more comprehensive and integrated science policy priorities (cf. Suomen Akatemia, 1988). 


\section{A communiçative view from the periphery}

The multifaceted problems of scientific integration are reflected in the patterns of scientific communication, which is a sensitive indicator of scientific interests, orientations and connections in the system of science. The study of scientific communication is essential for understanding the complexity of everyday functional mechanisms in science. It also brings us to the center - periphery problematique which, especially from the point of view of small countries like Finland, also seems relevant in this respect. The center - periphery location of countries and scientific communities is an important factor, which effects both the macrolevel structural development of science and the micro-level patterns of scientific communication (Fuhrman \& Kaukonen, 1988).

The center - periphery distinction is a metaphor which can be defined as referring to the objective material conditions of science (external criteria). As is well known, scientific and technological resources and activities are unequally distributed in the world and also within countries. The same unequal distribution also occurs between sciences as some fields have a more central position in S\&T priorities than others, and hence more resources, prestige and power. In addition to resources, the size of the country and the scale of scientific activities, there are also other objective factors which have an impact on the center-periphery position of countries, such as physical location and language, which affect accessibility to the international scientific community. Even political and cultural factors have an impact in this regard.

The size of research infrastructure and the quality of scientific output are no doubt interconnected, but their relationship need not be, and to be sure is not, linear. In this respect the differences between various scientific fields and disciplines are essential (see Whitley, 1984), especially in the sciences that may have a strong national (or even local) character and emphasis, e.g., social sciences, ethnographical research and problem oriented public health research. In these scientific fields it may be difficult or even impossible to define any international "centers of excellence". In the social sciences, for instance, various theories and methods can be imported and exported but often not concrete, nationally relevant research results.

In general we may state that the degree of national specificity vs, internationality (or universality) objectively varies among scientific fields and, concomitantly, so does the bearing of the centerperiphery distinction on different fields of science (cf. Trent, 1978). It may even be so, that nationally (or regionally) specific sciences become subject to external influences to the extent that their indigenious development will suffer from it (cf. Galtung, 1981). This has clearly been the case in many developing countries (see Rahman, 1972; Shiva and Bandyopadhuay, 1980; for a case of a European colony see Yearley, 1989). In the case of truly universal sciences, e.g. high energy physics, the critical question is different: what is their use and relevance, outside prestige and purely academic reasons, for a small peripheral country? Is their pursuit always worth the substantial investments and the dues needed to participate in expensive international programs? (E.g. CERN; Kriege, 1989).

There is some evidence that the scientific communication and collaboration between small, peripheral countries may be reciprocally intensive and in some fields may carry even more substantial results than that with the big center countries. In this regard one can heuristically consider the potential positive aspects of being at the periphery.

First, peripheral countries and their scientific communities in a way 'wrestle in the same weight category' and, being relatively outside the center dominated hierarchies in science, they may be more open to dialogue and collaboration on the basis of mutual interests. Second, the peripheral lag in development and the smaller scale of scientific activities need not necessarily be dysfunctional in every respect and in all fields of science. As a result of the scarcity of available resources, the differentiation of science has not, at least institutionally, gone as far as in the big centers of science. Therefore also the problems studied and approaches used are often broader and more integrative than those in the center. Latecomers may also selectively utilize the new potential created by the leading centers (e.g. Tsurumi, 1977).

When science is practiced on a smaller scale and outside the mainstreams, this often forces the individual scholar to follow and cover a relatively wide area of research and to gather ideas from many directions and centers - even from various linguistic areas. It has been claimed that the growth of scientific capital results in increasing competition and concomitant pressure towards homogeneity (Bourdieu, 1975), as well as in avoidance of scientific risks and in strengthening of conservative tendencies (Lemaine, 1980). In contrast, a peripheral position may give more room for intellectual freedom and creative eclecticism, assuming that the scientific communities gain enough independence to avoid the identity crisis which easily threatens them in the shadow of dominant centers (Galtung, 1981). 
In small countries the scarcity of resources effects the conditions of scientific activity in many ways. If they aim at the same coverage of research fields as the bigger ones do, the network of researchers becomes thinner, with less manpower in different fields of study. A paradoxical situation easily occurs: a Finnish academic researcher, for example, may personally know almost all of his/her colleagues in the country - or the whole staff in a "rural" university - but may not have a single domestic colleague or partner with whom to discuss his/her special area of research. This creates problems of scientific criticism, commentary, and evaluation as well as difficulties in developing collective forms of scientific work, all of which are important factors in maintaining lively scientific traditions. Hence the need of international contacts even in nationally specific research areas.

The continuing differentiation of science thus produces a number of problems for small scientific communities and necessitates them to be selective in research efforts. But this structural development is not necessarily less problematic in the big centers, where research problems may sometimes be sophisticated to the degree that it is not easy to conceive of them as societally relevant problems at all, when looking from the periphery.

\section{Concluding remarks on future perspectives}

The social world is becoming not only more complex, but also more indivisible due to the new global connections of ecology, economics, politics, and culture. World and local societies will face an increasing number of problems that cannot be understood and solved without complex, integrated approaches. Besides, it is becoming obvious that 'loçal' is no more something very different and distant from 'global'; the global problems and processes manifest themselves locally and are faced at the community level and therefore cannot be solved from above only. In this sense the wellknown saying "think globally, act locally" is becoming more actual and to the point.

In the future there will be a growing societal demand on science, both from governments and from civil society, to develop integrative, problemoriented research programs and thus help the society to manage and survive. This may bring the traditionally separated 'scientific' and 'policy' problems closer to each other. Contrary to recent trends, it is also obvious that the role of social sciences must be taken more seriously in these programs.
The need for more 'holistic' theories of the complexity of nature, society and wo/man sets great and serious challenges for scientific actors, institutions and the sponsors of science. Paradoxically, however, different sectors of research activity are still isolated from each other and function on different or even contradictory principles. Clearly, the cognitive potential for integrative research is much greater than is actually realized because of institutional and science policy restraints. Where is the place for cognitive work of integrative approaches? The critical question concerns the future sources of interest and support for this kind of research.

Our vision is that, in addition to the present mighty sponsors of research - the state and the business world - the importance of civil society, both as a supporter and an actual locus of research, will grow in the future. This notwithstanding the diversity of civil society activities ranging from voluntary associations and alternative movements to semiofficial, state sponsored organizations. As Elzinga (1988) has noted, the articulation of interests and demands for research from this side usually still is a problem and often presupposes the existence of a popular movement (e.g. environmental movements; see Cramer et al., 1987). Another major restraint of 'civilian science' is the scarcity of own resources (the material more scarce than the intellectual!) available for research, which results in dependency on public and other sources of support for research activities.

In his insightful article of 1981 Nakayama was optimistic and even positive that the future of science belongs to this kind of 'service science', which is sustained by a sense of solidarity with the average citizens and a concern for the common welfare. Interestingly, Nakayama also emphasizes that close contacts with the people are necessary for the proper identification of complex, integrative research problems - for service science the role of the laboratory approach is only supplementary.

The structural diversification and fragmentation of science has been caused by multiple interconnected factors: cognitive, communicative, institutional and social (science policy). Similarly, in order to make progress in the integrative direction, the influence of the same factors should be taken into account. In general terms, integrative research presupposes new priorities in science policy, more dynamic forms of organizing research, collective and open utilization of relevant cognitive potential, and intensification of scientific communication. In a word, new atmosphere and mechanisms should be 
created to strengthen the position and status of interdisciplinary research and other forms of scientific cooperation. In meeting these demands the development of academic science, as the most open and transparent sector of research and as the main reproducer of scientific traditions and intellectuals, will be crucial. To maintain and reinforce its scientific position and relative autonomy, the academic community has to cross academic boundaries, both internal and external. There is no other way to cope with the Scylla of academic isolation and the Charybdis of instrumental policy functionalism and entrepreneurialism.

\section{NOTES}

1. In Finland the universities' autonomous share of public R\&D funding has decreased from $42 \%$ in 1970 to 26 $\%$ in 1986. At the same time, the share of external funding in university based research has grown substantially and presently constitutes some $40-45 \%$ of research expenditures in the universities. (Kaukonen, 1986; Seppälä, 1987).

2. As a consequence of perestroika, though, the USSR Academy of Sciences is undergoing a major restructuring characterised by transition from fixed plans to more flexible project financing, increasing competition and economic accountability.

3. According to a present estimate the proportions in Figure 1 are: (1) academic science $14 \%$ (universities $10 \%$ and The Academy of Finland $4 \%$, (2) governmental R\&D $24 \%$ and (3) private sectoral/ industrial R\&D $62 \%$.

4. Nakayama presents strong arguments for the development of a fourth sector of research - service science - sustained by a sense of solidarity with average citizens and a concern for common welfare. While sympathizing with this idea, we should not underestimate the institutional opposition and financial restraints it inevitably meets.

5. Beginning from the 1970 's extensive meetings around this theme have been organized by the Soviet Academy of Sciences (e.g. the Obninsk conference in 1978 with more than a hundred papers presented; see Vsesojuznaja..., 1978|-II). The profile of these meetings has been philosophically oriented while relatively little attention has been paid to institutional and other 'down-to-earth' problems of scientific integration.

6. Interestingly, this development was criticized by Withelm von Humboldt as early as 1792 in his outline for the study on the 'History of whoring' (Humboldt, 1908; see also Haeberle, 1986). Von Humboldt also created a language philosophy based on the paradigm of dialogue and mutual understanding, including nonEuropean cultures.

7. Compared with the philosophically oriented Soviet discussions a recent Western contribution by Chubin et al. (1986) represents the other end; problems of interdisciplinary research are viewed as mainly technical and, hence, to a certain degree solvable with the help of an instructive handbook.

\section{REFERENCES}

Alestalo, $\mathrm{M}$.

1981 Tutkimustulosten hyödyntäminen ja metsäntutkimus (Utilization of research results: the case of forest research). Helsinki: Metsäntutkimuslaitoksen tiedonantoja 25.

Bourdieu, $P$.

1975 "The specificity of scientific field and the social conditions of the progress of reason." Social Science information, 14, 6: 19-47.

Bourdieu, P.

1988 Homo academicus. London: Polity Press.

Broesterhuizen, E. and Rip, A.

1984 "No PLACE for CUDOS." EASST Newsletter, 3, 3: $19-47$.

Chubin, D. et al. (eds.)

1986 Interdisciplinary Analysis and Research: Theory and Practice of Problem-focused Research and Development. Mt. Airy, Maryland: Lomond.

Cramer, J., Eyerman, R. and Jamison, A.

1987 "The Knowledge Interests of the Environmental Movement and Its Potential for Influencing the Development of Science." Pp. 89-115 in Blume, $S$, et al. (eds.), The Social Direction of the Public Sciences. Sociology of the Sciences Yearbook, Vol. XI. Dortrecht: D. Reidel.

Elias, N.

1982 "Scientific Establishments." Pp. 3-70 in Norbert Elias, Herminio Martins and Richard Whitley (eds.), Scientific Establishments and Hierarchies. Dortrecht: D. Reidel.

Elzinga, $A$.

1988 "The consequences of evaluation for academic research." Science Studies, 1, 1:5-14.

Elzinga, $A$. and Jamison, $A$.

1981 Cultural Components in the Scientific Attitude to Nature: Eastern and Western Modes? Discussion paper 146. Lund: Research Policy Institute, University of Lund.

Etzkowitz, $\mathrm{H}$.

1983 "Enterpreneurial Scientists and Enterpreneurial Universities in American Academic Science." Minerva, 21, 2-3: 198-233.

1989 "The commercialization of university science." Paper presented at the Advanced Studies Institute on "Managing Science in a Steady State", II Ciocco, October 10. (Unpublished).

Fuhrman, E.R. and Kaukonen, E.

1988 "On the circulation and legitimation of social science knowledge:the case of Finnish sociology." Social Epistemology, 2, 1: 43-59.

Galtung, J.

1981 "Structure, Culture and Intellectual Style: an Essay Comparing Saxonic, Teutonic, Gallic and Nipponic Approaches." Social Science Information, 20, 6: $817-856$. 
Gibbons, M. and Wittrock, B. (ed.)

1985 Science as a Commodity: Threats to the Open Community of Scholars. Essex: Longman.

Gieryn, T.F

1983 "Boundary work and demarcation of science from non-science: strains and interests in professiona ideologies of scientists." American Sociological Review, 48, 6: 781-795.

Granö, 0

1981 Forskningen istöpsleven. Östervăla: Delegationen för långsiktsmotiverad forskning/ forskningsrådsnämnden.

Gusdorf, G.

1977 "Past, present and future of interdisciplinary research." International Social Science Journal, 29, 4: $580-600$

Irvine, J. and Martin, B.

1984 Foresight in Science: Picking up the Winners. London and Dover N.H.: Farnces Pinter (Publishers).

Haeberle, E. J.

1986 "Sexualwissenschaft als Kulturwissenschaft: zur Diskussion vor 1930." Pp. 37-54 in Rolf Gindorf and Erwin J. Haeberle (Hrsg.), Sexualität als Sozialer Tatbestand. Berlin, New York: Walter de Gruyter.

Hamburg, D. A. and Brown, S. S.

1978 "The Science Base and Social Context of Health Maintenance: An Overview." Science, 200, Number 4344: 847-859.

Humboldt, W. von

1908 "Geschichte der Abhängigkeit in Menschengeschlechte." Gesammelte Schriften, Band VII. Berlin: Königlich Preussische Akademie der Wissenschaften.

Kara-Murza, S.G

1986 "Organizatsionnaja struktura nauki kak stredstvo intensifikatsii truda utshonyh" (Organizational structure of science as a means of intensifying the work of scientists). Sotsiologitsheskije Issledovanija, 12, 2: 25-36.

Kaukonen, $\mathrm{E}$

1985 "Tiede ja tieteentutkimus: eräitä teoreettis metodologisia ongelmia." (Science and science studies: some theoretical anc thodological problems). Pp. 223-248 in Erkki Kaukonen, Juha Manninen and Veli Verronen, Tieteen historia ja tieteellinen edistys (The History of Science and Scientific Progress). Helsinki: The Academy of Finland.

1986 Tieteen organisaatio ja tiedepolitiikka Suomessa (Organization of Science and Science Policy in Finland). Unpublished thesis in political science, University of Tampere.

1987 "Institutional Transformation of Finnish Science and Science Policy." Pp. 17-41 in Veronica StolteHeiskanen (ed.), Science Policy Studies from a Small Country Perspective. Helsinki: The Academy of Finland.
Kedrov, B. M.

1971 "Istorija nauki i printsipy jejo issledovanija" (History of science and principles of studying it). Voprosy Filosofii 25, 9: 78-89.

1975, 1976 Klassifizierung der Wissenschaften, Band III. Köln: Pahl-Rugenstein Verlag.

1980 "O sovremennoi klassifikatsii nauki: osnovnyje tendentsii $v$ jejo evolutsii" (Contemporary classification of science: basic trends of development). Voprosy Filosofii, 34, 10: 85-103.

Koivisto, $M$

1953 "Arvot, tiede ja tulevaisuus" (Values, science and future). Suomalainen Suomi 21, 8: 468-470.

Kon, I.

1979 Positivismi sosiologiassa. (Positivism in sociology). Moscow: Progress.

Kriege, J.

1989 "The international organization of scientific work: the case of CERN." Paper presented at the Advanced Studies Institute on "Managing Science in a Steady State", II Ciocco, October 5. (Unpublished).

Legay, J-M.

1986 "Science must consider the reality of complex systems." Scientific World, 30, 1: 19--20.

Lemaine, $\mathrm{G}$

1980 "Science normale et science hypernormale: les stratégies dedifférenciation et les stratégies conservatrices dans la science." Revue Francaise de Sociologie, 21, 4:499-527.

Lemola, $\mathrm{T}$. and Lovio, $\mathrm{R}$.

1989 "The relations between science and production in Finnish industry." Science Studies, 2, 1: 41-50.

Lähde, $\mathrm{E}$.

1988 "Metsätuhot tiedepolitiikan tuiverruksessa." (Forest damages in the turmoil of science policy). Tiedepolitiikka, 2: $32-34$.

Marx, K

1844 Taloudelliset-filosofiset käsikirjoitukset 1844 (Economic-philosophical manuscripts 1844). Moscow: Progress.

Merton, R. K

1973 The Sociology of Science: Theoretical and Empirical Investigations. Chicago and London: University of Chicago Press.

Mulkay, M. and Gilbert, G. N.

1983 "Scientists' Theory Talk." Social Studies of Science, $13,2: 179-197$.

Mäkelä, $\mathrm{K}$.

1981 Puheenvuoro Tieteen tilasymposiumis sa.(Comment in the symposium of The state of science. Research foundation on higher education and science policy). Korkeakoulu-ja tiedepoliittisen tutkimussäätiön monistesarja No 9. Helsinki:KTTS.

Nakayama, $\mathrm{S}$.

1981 "The Future of Research - a Call for a 'Service Science'." Fundamenta Scientiae, 2, 1:85-97. 
Our Common Future.

1987 World Commission on Environment and Development. Oxford: Oxford University Press.

Raa, J.

1987 "Faglig utarming av universitetene." Forskningspolitikk, 10, 1:15-17.

Radnitzky, G.

1983 "Science, Technology, and Political Responsibility." Minerva, 21, 2-3: 234-264.

Rahman, A.

1972 Anatomy of Science. Delhi: National.

Restivo, S.

1988 "Modern Science as a Social Problem." Social Problems, 35, 3 (June): 206-225.

Rosenthal, M. M. et al. (eds.)

1974 Geschichte der marxistischen Dialektik: von der Entstehung des Marxismus bis zur leninschen Etappe. Berlin: VEB Deutscher Verlag der Wissenschaften.

Seppälä, E-O.

1987 "Suomen korkeakoulujen tutkimusrahoituksen kehitys 1970-luvulta lähtien." (Development of research funding in Finnish universities since 1970s). Tiedepolitiikka, 3: 29-31.

Shapere, D.

1986 "External and internal factors in the development of science." Science and Technology Studies, 4, 1: $1-9$.

Shiva, V. and Bandyopadhuay, J.

1980 "The Large and Fragile Community of Scientists in India. Minerva, 18, 4: 575-594.

Stolte-Heiskanen, $\mathrm{V}$.

1987 "Comparative Perspectives on Research Dynamics and Scientific Performance: a View from the Periphery." R\&D Management, 17, 4: 253-262.

Suomen Akatemian toimintalinjat.

(The guidelines of the Academy of Finland)

1988 Helsinki: Valtion painatuskeskus.

Titmonas, A.

1974 "K voprosy opredposylkah institutsionalizatsii nauki" (On the preconditions of institutionalization of science). Pp. $158-173$ in V. Kelle and S. R. Mikulinski (eds.), Sotsiologitsheskije Problemy Nauki (Sociological Problems of Science). Moskva: Nauka.

Trent, J.

1978 "Internationalization? Interdisciplinarity? Development?" Social Science Information, 17, 2: $337-342$.
Tsurumi, $\mathrm{K}$.

1977 "Some Potential Contributions of Latecomers to Technological and Scientific Revolution: A Comparison between Japan and China." Pp. 147173 in RolfDahrendorfet al., Scientific-technological Revolution: Social Aspects. London: Sage (Studies in InternationalSociology 8).

Volkov, $\mathrm{H}$.

1976 Istoki i gorizonty progressa (Origins and horizons of progress). Moskva: Izdatelstvo polititsheskoi literatury.

Vsesojuznaja konferentsija "Metodologitsheskije aspekty vzaimodeistvija obsheshestvennyh, jestestvennyh i tehnitsheskih nauk $v$ svete reshenij XXV Sjezda KPSS" (Federal conference on "Methodological aspects of the interaction of social, natural and technical sciences in the light of XXV Party congress decisions").

1978 Moskva-Obninsk: Sovetskoje natsionalnoje objedinenie istorii i ilosofii jestestvoznanija i tehniki (i dr.).

Whitley, $\mathrm{R}$

1974 "Cognitive and social institutionalization of scientific specialties and research areas." Pp. 69-95 in Richard Whitley (ed.), Social Processes of Scientific Development. London and Boston: Routledge \& Kegan Paul.

1984 The Intellectual and Social Organization of the Science. Oxford: Clarendon Press.

Yakhiel, N.

1985 "Nauka i burzhuaznaia sotsiologitsheskaja mysl: ot normativnoi $k$ interpretivnoi sotsiologii nauki" (Science and bourgeois sociological thought: from normative to interpretative sociology ofscience). Voprosy Filosofii, 39, 5: 64-73.

Yearley, S.

1989 "Colonial science and dependent development: the case of the Irish experience." The Sociological Review, 37, 2: 308-331.

Ziman, J.

1984 "The Collectivization of Science," EASST Newsletter, 3, 2: 5-11.

Erkki Kaukonen and Pirkko-Liisa Rauhala University of Tampere

Department of sociology and social psychology

P.O. Box 607

33101 Tampere, Finland 